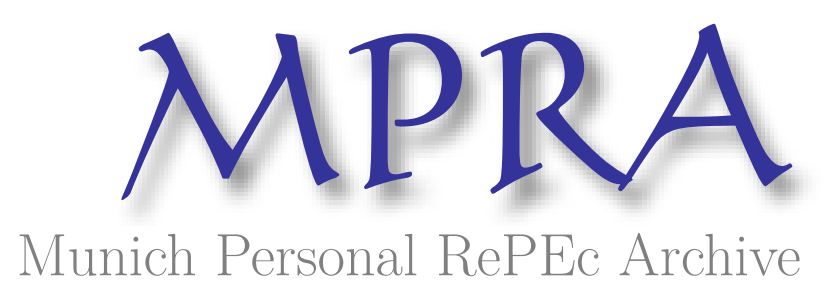

Foreign Aid and Corruption:

Anti-Corruption Strategies Need Greater Alignment with the Objective of Aid Effectiveness

\author{
Quibria, M.G. \\ Morgan State University
}

2017

Online at https://mpra.ub.uni-muenchen.de/85722/

MPRA Paper No. 85722, posted 16 Apr 2018 13:57 UTC 


\section{Foreign Aid and Corruption: Anti-Corruption Strategies Need Greater Alignment with the Objective of Aid Effectiveness}

\section{By M.G. Quibria}

\section{Introduction}

The history of foreign aid ${ }^{1}$ has been inextricably linked with corruption. Since the inception of the International Development Association (IDA) in 1960, a large body of writings has emerged on the corrosive effect of corruption that undermines the effectiveness of foreign aid. Starting with the eloquent writings of Peter Bauer, ${ }^{2}$ the theme has continued to resonate to this day in the academic, as well as popular, discourse. In a recent, high-profile, and popular book, Dead Aid, Mayo ${ }^{3}$ went so far as to argue that the root cause of much of the development affliction of Africa can be traced to a large inflow of foreign aid. This, she argues, generates a cycle of corruption that results in a slower growth and greater poverty.

According to the former UN Secretary-General Ban Ki-Moon ${ }^{4}$, corruption devours about 30 percent of all development assistance or aid money that never makes it to the final destination. By necessity, such numbers are largely guess estimates; nevertheless, they indicate the existence of an insidious challenge facing the international development community.

\footnotetext{
${ }^{1}$ We use the term foreign aid to refer to grants and concessional loans provided by bilateral and multilateral agencies to developing countries with the primary objective of promoting social and economic development. ${ }^{2}$ Bauer P, Dissent on Development: Studies and Debates in Development Economics, Revised Edition (Oxford: Oxford University Press, 1976).

${ }^{3}$ Moyo, Dambisa. Dead aid: Why aid is not working and how there is a better way for Africa. (New York: Palgrave Macmillan, 2009).

${ }^{4}$ Ki-Moon, Ban. UN News,9 July, 2012.http://www.un.org/apps/news/story.asp?NewsID=42430\#.WHDkEht97ic
} 
In view of the existing corruption problem, the international development community has taken a firm stance against it. For example, the World Bank ${ }^{5}$, which considers controlling corruption a priority, identifies corruption as a major challenge to its institutional goals of eradicating extreme poverty by 2030. Similar concerns about corruption have been expressed by the International Monetary Fund (IMF). In a recent paper, IMF' considers corruption as "macrocritical" to its mandate of achieving macroeconomic stability. It further notes that corruption impedes the conduct of efficient budgetary and monetary policy and weakens financial oversight, thereby hurting inclusive growth. Similar stances have been taken by regional development banks. For example, the purpose of the Asian Development Bank's (ADB) Anticorruption Policy, approved in July 1998, is to reduce the burden corruption exacts from the governments and economies of the region. The policy has three objectives: support competitive markets and effective public administration, support explicit anticorruption efforts, and ensure ADB-financed projects and its staff adhere to the highest ethical standards. Despite the resolute donors' stance against corruption, corruption continues to besmirch the delivery of international aid to developing countries.

\section{Corruption: Definition, Type and Measurement}

Although different people use the term "corruption" to imply different things, we will adhere to a notion that is most commonly employed by economists, which is the "use of public office for private gains.' This essay will, thus, exclude private sector corruption and concentrate on public sector corruption, which comes in two genres: bureaucratic corruption and political

\footnotetext{
${ }^{5}$ Kim, J.H. "Tackling Corruption to Create a More Just and Prosperous World." Lecture Delivered at the AntiCorruption Summit, London, 2016.

${ }^{6}$ International Monetary Fund(IMF). Corruption: Costs and Mitigating Strategies. Staff Discussion Note 16/5 (Washington, D.C.: IMF, 2016)
} 
corruption. The nature and prevalence of these two types of public corruption varies from country to country, depending on the nature of the political regime. ${ }^{7}$

Corruption is a covert and collusive activity that may involve different layers of government - from the top of the hierarchy at the policy and decision-making level to the lower layer of the government at the implementation level - both political as well bureaucratic.

Corruption takes various forms and occurs at different stages of a project. Contractors and consultants pay bribes - or promise to pay bribes - to government officials for project contracts. An example of the latter genre is the Padma Bridge, a multibillion dollar infrastructure project for Bangladesh, which was to be financed by the World Bank and many other financing donors. Prior to the start of loan, the World Bank launched an investigation into allegations that high-level government officials were arranging to award a project-related contract to a specific consortium, led by SNC Lavalin International, Inc. in exchange for bribes. ${ }^{8}$ Such graft-conspiracy cases, which are often difficult to prove, can be a potent source of international controversies. ${ }^{9}$

Corruption often takes the form of bid rigging to exclude other competitors followed by fraud to recover the costs of the bribe. The various types of fraudulent practices include contract

\footnotetext{
${ }^{7}$ Bardhan, Pranab. "The Economist's Approach to the Problem of Corruption," World Development, vol. 34(2) (2006): 341-348.

${ }^{8}$ Quibria, M.G., Anika Islam. "A Case Study of Aid Effectiveness in Bangladesh: Development with Governance Challenges," in Handbook on the Economics of Foreign Aid, Edited by B. Mak Arvin, and Byron Lew (London: Edward Elgar, 2015).

${ }^{9}$ In this case, the World Bank investigation led to the arrest and indictment of two senior officials of SNC Lavalin by the Canadian authorities under the Canadian Corruption of Foreign Public Officials Act as well as to the eventual cancellation of the World Bank loan. However, the anti-corruption commission of the Bangladesh government did not find the evidence of corruption provided by the World Bank convincing. A similar judgment was recently reached by the Canadian court which dismissed the case against the Lavalin officials - as it found the wiretap evidence, provided by the Canadian authorities, as "nothing more than speculation, gossip and rumor". See, Janet McFarland. "Former SNC executives, businessman acquitted in corruption case." Globe and Mail (Toronto, Canada), Feb. 10, 2017. This graft-conspiracy case, which seems to represent an instance of overzealous pursuit of corruption by the Bank, has generated a good deal of resentment within the country. While the government is currently completing the project with its own resources, this imbroglio has caused a significant delay in initiating the construction of the bridge. As a result, there has been a considerable escalation of costs, thereby creating a much larger fiscal burden for the society.
} 
amendments and extensions, as well as obtaining quality certifications when the project does not meet the standard of certification or when the delivery of goods and services occur at a suboptimal level. Contractors and consultants also often inflate costs and bill for works that were never performed or performed at a substandard level. Public officials - both politicians and bureaucrats - also indulge in fraudulent practices, such as establishing their own NGOs and phony companies to attract funds from aid programs. Furthermore, project officials often divert project equipment, such as automobiles and computers, for personal use and also misuse project money for unnecessary procurement and foreign trips for study tours, trainings, or to meet with suppliers.

Given the covert and collusive nature of corruption, it is difficult to detect, identify, and measure. Although much has been written about the insidious impact of corruption, measuring corruption from foreign aid remains a challenge. Much of this challenge has to do with the clandestine nature of corruption, which is not amenable to direct observation and measurement. The existing estimates of corruption are, therefore, largely based on perceptions of corruption rather than on observation of any objective data. Such estimates can be biased for various reasons. ${ }^{10}$ First, there is the complex problem of translating perceptions into quantities. This problem is further compounded by the fact that perceptions do not necessarily reflect objective reality - that is, perceptions of corruption are not the same as the actual state of corruption. Second, perceptions can be biased due to the "halo effect," which arises from experts making similar errors when considering the same country. This correlation in the perception errors is due to the fact that experts rely on the same data sources or similar media reports for assessing an

\footnotetext{
${ }^{10}$ See Quibria, M.G. “Data on Indicators of Governance: Handle with Care,” World Economics, 17(2) (2016b), 125142.
} 
individual country. Finally, many of the corruption indicators are based on the assessments of foreign respondents, whose perceptions can be biased for ideological and cultural reasons (since social norms vary across societies).

The standard corruption measures compress a large amount of complex information into a single number for a country for a given year. The underlying data can be quite heterogeneous, and the weight accorded to a particular type of data can be arbitrary. Consider, for example, in some countries corruption can be petty and pervasive, while in others it may involve a few but major cases comprising large sums of money. Similarly, the major types of corruption in some countries can be bureaucratic, while in others it can be political. Additionally, in some corruption can simply take the form of fraudulent practices without explicit financial transactions. Different individuals can have different perceptions about varying types of corruption and rank them differently. It has been suggested that, given the diversity of values and the heterogeneity of indicators, there is no index of corruption that can meaningfully capture all such complexities into a single number. ${ }^{11}$

\section{Interrelationship Between Foreign Aid and Corruption}

The empirical relationship between foreign aid and corruption is complex. Foreign aid, on the one hand, can contribute to an improvement of the quality of governance; this improvement can take place due to an improvement in the efficiency of civil servants and a reduction in corruption due to increasing civil servant salaries, as well as the implementation of institutional reforms. On the other hand, in some instances, aid can also create perverse incentives for recipient countries not to mobilize savings or to undertake serious governance

${ }^{11}$ Quibria, M.G. “Data on Indicators of Governance: Handle with Care,” World Economics, 17(2) (2016), 125-142. 
reforms for addressing corruption. ${ }^{12}$ The net outcome of these countervailing influences is likely to differ from country to country.

\section{Controlling Corruption in Foreign Aid}

Since the 1990s, corruption has emerged as a major area of discussion by international aid agencies and recipient governments. This change reflects many factors, including changing geopolitical interests and stricter availability of foreign aid. The international donors, with the cooperation of aid recipients, have instituted various measures to combat corruption. While there is no magic cure for corruption, these measures appear to have had a tangible positive effect on controlling corruption. The following briefly discusses some of the salient measures.

Performance-Based Lending: The multilateral development banks (MDBs) base their aid allocation in part according to indicators of corruption. For the World Bank, the annual allocation of IDA resources is based on its annual Country Policy and Institutional Assessment (CPIA) exercise, which is an assessment of the quality of policy and institutional assessment. Governance, in particular corruption, is an important element of these assessments. Other multilateral development banks follow a similar methodology for their own aid allocation exercise. However, such an approach has been criticized for reflecting the Washington consensus - that its underlying assumption is prescriptive about the character of good policies and institutions - that it is ahistoric and blind to country-specific characteristics and that its rating process lacks internal consistency and is not sufficiently robust. ${ }^{13}$

\footnotetext{
${ }^{12}$ Quibria, M G. “Aid effectiveness: Research, Policy and Unresolved Issues,” Development Studies Research: An Open Access Journal (2014): 75-87.

${ }^{13}$ Quibria, M.G. “Data on Indicators of Governance: Handle with Care,” World Economics, 17(2) (2016), $125-142$.
} 
The Millennium Challenge Corporation of the United States government has made anticorruption central to its aid allocation process. It offers two types of aid assistance: threshold and compact grants; for both types of grants controlling corruption is the key determinant. In order to qualify for aid, countries must score above average for their income group on the Worldwide Governance Indicators' (WGI) “Control of Corruption” score. However, this methodology has come under some serious criticisms. Some of the criticism relates to the reliability of the WGI as a measure of corruption. ${ }^{14}$ Other criticism relates to the lack of robust association between the WGI indicators and economic growth. ${ }^{15}$

The above performance-based lending is based on an assessment of inputs and activities, which is to be contrasted with an alternative mode of lending known as pay-for-results programs which disburse funds based on (ex post) outputs or outcomes. ${ }^{16}$ In recent years, aid agencies have implemented such programs for reduced deforestation, secondary school completion, childhood vaccination, and energy access. Under this program, donors and recipients agree on a set of goals and establish an amount to be disbursed in relation to each unit of progress toward those goals. Such agreements require the establishment of a quantifiable metric and verifying it accordingly. In principle, it provides the recipient full autonomy to pursue the best strategy it deems effective. Also, this requires little input in terms of donor monitoring and supervision; disbursements are made after the confirmation of the results. However, success of this type of

\footnotetext{
${ }^{14}$ Quibria, M.G. "Governance and Developing Asia: Concepts, Measurements, Determinants and a Paradox," in Governance in Developing Asia, Public Service Delivery and Empowerment, Edited by Anil B. Deolalikar, Shikha Jha and Pilipinas F. Quising (London: Edward Elgar, 2015b).

${ }^{15}$ Quibria, M.G. "Does Governance Matter? Yes, No or Maybe: Some Evidence from Developing Asia," Kyklos, Wiley Blackwell, vol. 59(1) (2006): 99-114.

${ }^{16}$ These two types of lending modes are also known as policy-based conditionality and outcome-based conditionality. The relative merits and demerits of these modalities are discussed in Quibria, M G. "Aid effectiveness: Research, Policy and Unresolved Issues," Development Studies Research: An Open Access Journal (2014): 75-87.
} 
lending depends on a mutually agreed, verifiable metric which can be a source of contention in practice.

Strengthening the transparency and accountability of donors: In recent years, the donor agencies have built upon and strengthened their existing institutions of inspection, auditing, and policy dialogue with recipient countries ${ }^{17}$ During this period, all of the MDBs have created new departments and instituted procedures to improve their integrity. Specifically, they have adopted whistleblowing mechanisms, expanded internal and external auditing procedures, created investigative offices - for example, the Asian Development Bank's Office of Anticorruption and Integrity and the World Bank's Integrity Vice-Presidency, revised codes of ethics for staff, established semi-judicial procedures for imposing sanctions on contractors, and negotiated collective agreements on debarment. Coordination among the MDBs has required further negotiations to establish the basis under which decisions in one institution can serve as the basis for actions in another, as in the case of cross-debarment rules. Such control mechanisms represent the most systematic effort by donor agencies to improve the integrity of their programs. There has been a significant expansion of staff and offices to discharge these functions.

Although the above measures to strengthen transparency and accountability of donors have had a positive bearing on corruption, these measures involve large costs; they often work cross-purposes with aid effectiveness because they are designed more to protect the donors' reputation than to achieve development results.

\footnotetext{
${ }^{17}$ Savedoff, William. "Anti-Corruption Strategies in Foreign Aid: From Controls to Results." CGD Policy Paper 076. Washington DC: Center for Global Development, 2016. http://www.cgdev.org/publication/assessing-us-feedfuture-initiative-new-approach-food-security.
} 
Improving the transparency and accountability of recipients: In addition to addressing their own accountability, bilateral and multilateral agencies have sought to improve the transparency and accountability of recipients. These activities include support for creating anticorruption commissions, building investigative and judicial institutions, implementing new public procurement systems, and improving public financial management practices.

Efforts have also been made to create "external accountability" mechanisms by strengthening civil society groups and by engaging in consultations with local groups. In addition to ensuring stakeholders' support of local projects, such consultations are a useful vehicle for disseminating information about projects. Such stakeholders also act as monitors of project progress, report on various deficiencies of project implementation and provide feedback on potential corruption.

The success of such external accountability mechanisms depends on the level of transparency in government operations and the existence of an independent media to expose and disseminate important information. As a result, in recent years, the international aid agencies have supported programs, in some countries, to strengthen the local media.

It may be noted that these measures for enhancing transparency and accountability at the recipient level are likely to yield limited results unless they are domestically owned. In some countries they exist as alien institutions without much political support; they act as window dressing without having much impact on corruption.

Global anti-corruption campaign: Recent years have seen an upsurge of a global campaign against corruption, leading to the creation of a set of global public goods that provide standards, services, or institutions that benefit the global community. They include legal conventions that 
facilitate international cooperation in prosecuting fraud and abuse, such as the OECD AntiBribery Convention and the United Nations Convention Against Bribery; initiatives to increase the transparency and accountability of international transactions, such as the Extractive Industries Transparency Initiative, the Financial Action Task Force on Money Laundering or the International Aid Transparency Initiative; development of protocols for international cooperation on recovering stolen assets, tracking the assets of prominent persons, and pursuing criminal investigations; and support networks for those engaged in high-level anti-corruption investigations (e.g. the International Corruption Hunters Alliance). ${ }^{18}$ All these investments in global public goods for controlling corruption have been helpful, yet they do not contribute directly toward progress against corruption in a specific country.

The above global anti-corruption initiatives have proceeded side by side with intensified efforts at data collection; these efforts have led to the production of various indices and rankings of corruption, which include the corruption perception index by Transparency International and the WGI by the World Bank. Despite significant improvements in data collection, they have many lacunas including the fact that they do not provide any definitive idea on the nature and extent of improvements in corruption over time.

Nevertheless, one thing is widely believed that even though corruption still exists, it seems to be on the decline. In a recent essay in The Wall Street Journal, "The Three Myths on the World's Poor," Bill Gates and Melinda Gates argue that though some foreign aid gets wasted on corruption, the problem today is "much smaller." They further note "The horror stories you

\footnotetext{
${ }^{18}$ Savedoff, William. "Anti-Corruption Strategies in Foreign Aid: From Controls to Results." CGD Policy Paper 076. Washington DC: Center for Global Development, 2016. http://www.cgdev.org/publication/assessing-us-feedfuture-initiative-new-approach-food-security.
} 
hear - where aid just helps a dictator build new palaces - mostly come from a time when aid was designed to win allies for the Cold War rather than to improve people's lives." 19

There are few societies that have completely eradicated corruption. Even in rich societies there is corruption, though of a different type than exists in developing countries, such as tax evasion, lobbying, and political capture. In light of this global experience, it is foolish to expect a complete eradication of corruption from much poorer developing countries. Nevertheless, it is encouraging that the recent integrity measures promoted by the international development community have had a salutary effect on controlling corruption across developing countries (although their impacts may not be uniform across societies). Despite this progress, it appears that the recent campaign against corruption has reached a point of diminishing returns in terms of aid effectiveness. ${ }^{20}$

\section{Concluding Remarks}

Combating corruption is not an end in itself; it is a means to an end (i.e., attaining aid effectiveness). There are many reasons why an aid project can fail, and corruption is one of them. The current approach to fighting corruption emphasizes major institutional changes that include creation of new departments, implementation of new procedures and strengthening of prosecution; they have little or no direct bearing on the results foreign aid seeks to achieve such as inclusive growth, efficient service delivery or environmental sustainability.

\footnotetext{
${ }^{19}$ Gates, Bill and Melinda Gates, "Three Myths on the World's Poor," Wall Street Journal (New York), Jan.17, 2014).

${ }^{20}$ The recent 2015 annual report of Independent Evaluation Group of the World Bank suggests that the performance of World Bank projects which are rated as successful (moderately satisfactory and above) seems to have reached a plateau in recent years. See, Independent Evaluation Office, "Results and Performance of the World Bank Group 2015.” Washington, DC: World Bank, 2016.
} 
If the current anti-corruption campaign has to contribute to aid effectiveness, it should be subsumed under the strategy for achieving aid effectiveness. This reframing will have the following implications. ${ }^{21}$ First, this would require streamlining the current unsystematic effort at allocating donors' investigative resources that are currently allocated on the basis of complaints, regardless of their development impact. This would call for prioritizing the allocation of investigative resources where corruption has the most adverse effects on development results. ${ }^{22}$

Second, the international donors have instituted a whole series of corruption control mechanisms involving fiduciary rules, procurement rules and financial management reforms, among others. These control mechanisms require, for their success, intensive monitoring by international agencies. Despite extensive oversight, many of these control mechanisms have often been unutilized or underutilized (i.e., they are applied to a small sample of the recipient countries' investment portfolios) with little or no impact on corruption or development results. Part of this may have to do with the alien nature of some of these control mechanisms and partly due to lack of capacity. To devise a repertoire of effective control mechanisms, further research is required on the relative costs of various control mechanisms in relation to their development impacts. This research could assist donor agencies to improve on the existing control mechanisms by jettisoning those that are ineffective or too expensive in relation to development results and by replacing them with practices that are indigenous, owned by the country and

\footnotetext{
${ }^{21}$ Savedoff, William. "Anti-Corruption Strategies in Foreign Aid: From Controls to Results." CGD Policy Paper 076. Washington DC: Center for Global Development, 2016. http://www.cgdev.org/publication/assessing-us-feedfuture-initiative-new-approach-food-security.

${ }^{22}$ This prioritization can be guided by data on corruption in samples of programs stratified by their ability to generate results.
} 
broadly in line with accepted good practices, as agreed in the Paris Declaration of Aid Effectiveness. ${ }^{23}$

Thirdly, when the recipient government is too weak or too unscrupulous to handle aid resources, the donors need to devote a surpassingly high amount of resources on oversight and controls. One way to economize on such administrative resources is to adopt outcome-based selectivity-i.e., lending modalities that reward countries based on their past results (in health, education, poverty reduction etc.) - rather than the recipients' promise to adhere to various corruption-control mechanisms. Fourth, another lending modality, which has the potential to limit corruption, is Pay-for-Results as discussed earlier. This lending, which pays for actual expost performance, is by design and necessity less prone to corruption. However, success of this type of lending depends on the development of a mutually agreed, verifiable result-metric which can be independently adjudicated.

The above provides an outline of a preventative approach to limit corruption. However, a robust strategy to combat corruption needs to go beyond a preventative approach; it needs to be complemented by investments that improve the quality of government, such as education and training that strengthen human capital and augment the absorptive capacity, as well as measures to increase civil service salary.

${ }^{23}$ United Nations. "Paris Declaration on Aid Effectiveness." Feb28-March2, 2005. http://www.mw.one.un.org/wpcontent/uploads/2014/04/UN-Global-Paris-Declaration-on-Aid-Effectiveness.pdf 